\title{
Assessing some heavy metals pollutions in sediments of the northern Persian Gulf (Bushehr province)
}

\author{
Mehdi Bibak $^{1^{*}}$, Masoud Sattari ${ }^{1,2}$, Ali Agharokh ${ }^{3}$, Saeid Tahmasebi ${ }^{4}$, Javid Imanpour Namin ${ }^{1}$ \\ ${ }^{1}$ Department of Fisheries, School of Natural Resources, University of Guilan, Sowmehsara, Iran \\ ${ }^{2}$ Department of Marine Sciences, Caspian Sea Basin Research Center, University of Guilan, Sowmehsara, Iran \\ ${ }^{3}$ Research Center for Persian Gulf, School of Persian Gulf, University of Persian Gulf, Bushehr, Iran \\ ${ }^{4}$ Department of Statistics, School of Basic Sciences, University of Persian Gulf, Bushehr, Iran
}

\begin{abstract}
Background: Land and water pollution by heavy metals is a universal issue. Although the pollution affects all countries, but its range and severity vary hugely. The pollution of the marine environment by heavy metals is a worldwide problem. Marine sediments can be sensitive indicators for monitoring contaminants in aquatic environments.

Methods: The concentration of 10 elements ( $\mathrm{As}, \mathrm{Cd}, \mathrm{Cr}, \mathrm{Cu}, \mathrm{Al}, \mathrm{Fe}, \mathrm{Ni}, \mathrm{Pb}, \mathrm{Sb}$, and $\mathrm{Zn}$ ) was determined in the sediments of four shoreline stations including Imam Hassan port, Ameri port, Bushehr port, and Nayband Bay at the west Persian Gulf from March to December 2017. The elements were measured by inductively coupled plasma mass spectrometry (ICP-MS). Data were analyzed using SPSS version 16. Results: The contamination of the sediments was assessed based on the geoaccumulation index (Igeo) and enrichment factor (EF). Spearman correlation matrix was calculated between all the trace metals and major elements as well as corresponding sampling regions. Statistically significant inter-elemental correlations (e.g., $\mathrm{Cr}-\mathrm{Fe}, \mathrm{Cr}-\mathrm{Al}, \mathrm{Cr}-\mathrm{Ni}, \mathrm{Cr}-\mathrm{Zn}$, and $\mathrm{Cr}-\mathrm{Cu}$ ) were found between some metals. High $\mathrm{EF}$ levels for $\mathrm{Fe}$, $\mathrm{Al}$, and $\mathrm{Pb}$ suggest that metals in the sediments of the northern Persian Gulf could have originated from anthropogenic sources.

Conclusion: The contamination pattern of sediments is affected by factors such as sedimentation patterns, physical and chemical properties of the sediments. For example, sediments with fine-grained and high surface area-to-volume ratio can act as good absorbents for many pollutants.

Keywords: Heavy metals, Geologic sediment, Persian Gulf, Bushehr

Citation: Bibak M, Sattari M, Agharokh A, Tahmasebi S, Imanpour Namin J. Assessing some heavy metals pollutions in sediments of the northern Persian Gulf (Bushehr province). Environmental Health Engineering and Management Journal 2018; 5(3): 175-179. doi: 10.15171/EHEM.2018.24.
\end{abstract}

Article History:

Received: 30 June 2018

Accepted: 27 August 2018

ePublished: 20 September 2018

\section{Introduction}

The pollution of marine environment by heavy metals is a worldwide problem. Although the pollution affects all countries, but its range and severity vary hugely. In this regard, marine sediments can be sensitive indicators for monitoring contaminants in aquatic environments $(1,2)$. The sediments are used as a stock for heavy metals and thus, need special investigation in projecting aquatic pollution research. Accumulation of heavy metals happen in upsaid sediments in aquatic environments by biological mechanisms. Sediment is a habitat and major nutrient source for aquatic organisms. These processes become toxic to sediment-dwelling organisms, resulting in death, reduced growth, reproductive impairment, and prevent species diversity $(3,4)$. Heavy metals pollute marine sediments and other aquatic ecosystems, which happen due to industrialization $(5,6)$.

Great quantities of pollutants, directly or indirectly, are discharged into the marine environment every day. In this regard, heavy metals are considered as serious pollutants of the aquatic environments due to their accumulative behavior $(7,8)$. Heavy metals are one of the constituents that affect the marine ecosystems. Potential toxicity of heavy metals in an aquatic ecosystem is determined by their chemical form. Some elements are necessary for human health in trace amounts $(\mathrm{Co}, \mathrm{Cu}, \mathrm{Cr}$, and $\mathrm{Ni}$ ), while others are carcinogenic or toxic, mainly affecting the central nervous system $(\mathrm{Hg}, \mathrm{Pb}$, and $\mathrm{As})$, the kidneys or liver $(\mathrm{Hg}, \mathrm{Pb}, \mathrm{Cd}$, and $\mathrm{Cu})$, or skin, bones and teeth ( $\mathrm{Ni}, \mathrm{Cd}, \mathrm{Cu}$, and $\mathrm{Cr}$ ) (9). Heavy metals that have been recognized in the polluted environment include $\mathrm{As}, \mathrm{Cu}$, $\mathrm{Cd}, \mathrm{Pb}, \mathrm{Cr}, \mathrm{Ni}, \mathrm{Hg}$, and $\mathrm{Zn}$. The toxicity of trace metals 
arises from their interference with an organism's uptake of essential metal ions such as sodium and calcium. For example, cadmium and zinc block the uptake of calcium ions, which are important for bone and teeth growth. The interaction of some heavy metals with enzymes and their tendency to bind to the protein and other biological tissues also cause trace metal poisoning in organisms $(10,11)$.

The Persian Gulf is a relatively shallow semi-enclosed sea with poor flushing characteristics. Thus, pollution discharges into the sea are diluted more slowly than into open marine ecosystems (12). The Persian Gulf has been facing many environmental challenges like biodiversity loss, industrial pollution, and harmful effluents (13). Additionally, environmental incidents, ship traffic, transportation, oil pollutants, and oil spills can cause different pollutants including heavy metals $(14,15)$. Iran has the longest water joint border in the Persian Gulf and it has a way through the Strait of Hormuz and Makran Sea (Oman) to the Indian Ocean from the east. It leads to Arvand River in Khuzestan province from the west, which is composed of two Tigris and Euphrates rivers in Iraq as well as Karun River attachment in Iran (16).

The aim of this study was to determine the concentration of 10 metals (As, $\mathrm{Cu}, \mathrm{Cd}, \mathrm{Pb}, \mathrm{Cr}, \mathrm{Ni}, \mathrm{Zn}, \mathrm{Fe}, \mathrm{Al}$, and $\mathrm{Sb}$ ) in sediments of the Persian Gulf.

\section{Materials and Methods}

Bushehr is located at $28^{\circ} 55^{\prime} 19.84^{\prime \prime} \mathrm{N}$ and $50^{\circ} 50^{\prime} 4.76^{\prime \prime}$ $\mathrm{E}$ in southwestern Iran and around the northern of the Persian Gulf. In this study, 12 sampling sites in four regions of Imam Hassan port, Bushehr port, Ameri port, and Nayband Bay (Figure 1) were selected during March to December 2017.

Samples were obtained from the upper layer $(5 \mathrm{~cm}$ depth) of sediments. Ten square meters of each area was sampled. The sediments were collected from the intertidal areas once low tides. Sediments were transferred to polyethylene containers and transported to the laboratory at $4^{\circ} \mathrm{C}$. The

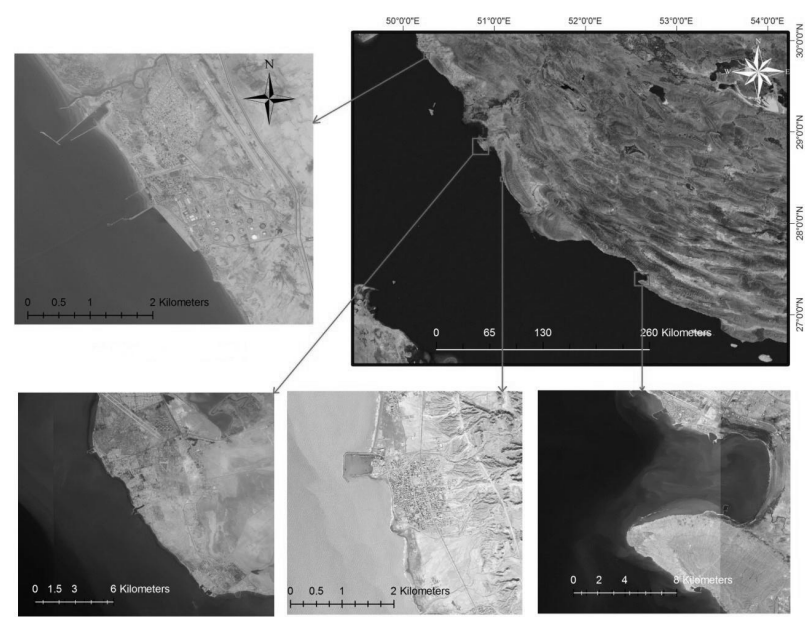

Figure 1. Sampling areas. samples were dried at $105^{\circ} \mathrm{C}$ for at least 24 hours (17). The samples were sieved through a 63 micron stainless steel sieve and agitated vigorously to produce homogeneity (18). One gram of each sample was digested in a mixture of concentrated $\mathrm{HNO} 3(65 \%)$ and $\mathrm{HClO} 4(60 \%)$ in the ratio of $4: 1$, first, at a low temperature $\left(40^{\circ} \mathrm{C}\right)$ for 1 hour and then, at a high temperature $\left(140^{\circ} \mathrm{C}\right)$ for 4 hours (19). The digested samples were then diluted to a certain capacity $(25 \mathrm{~mL})$ with double distilled water (DDW). The sample was then filtered through Whatman No. 40 filter paper. The heavy metals concentrations were determined by inductively coupled plasma mass spectrometry (ICPMS) (scheme code was MMS-01: Detection limited were in ppm) in Zarazma Co.

The geoaccumulation index (Igeo) is used to determine the level of contamination in sediments (20). For this purpose, the current concentrations is compared to preindustrial levels using the following equation:

$\mathrm{I}_{\text {geo }}=\log _{2} \mathrm{C}_{\mathrm{n}} / 1.5 \mathrm{~B}_{\mathrm{n}}$

where $C n$ is the measured concentration of the element $\mathrm{n}$ in the pelitic sediment fraction $(<2 \mathrm{Am})$ and $\mathrm{Bn}$ is the geochemical background value in fossil argillaceous sediment (average shale). The quality of the sediments is divided into six classes by Igeo: unpolluted (Igeo < 0 ), unpolluted to moderately polluted $(0<$ Igeo $<1)$, moderately polluted $(1<$ Igeo $<2)$, moderately to strongly polluted $(2<$ Igeo $<3)$, strongly polluted $(3<$ Igeo $<4)$, strongly to extremely polluted $(4<$ Igeo $<5)$, and extremely polluted $(5<$ Igeo). Concentrations of the geochemical background are increased each time by the constant 1.5 in order to allow value fluctuations of a given substance in the environment as well as very small anthropogenic influences (21).

The enrichment factor $(\mathrm{EF})$ is based on the standardization of a tested element against a reference one. According to contamination standards based on the EF, the following classes are obtained: $\mathrm{EF}<2$ (deficiency to minimal enrichment), $2 \leq \mathrm{EF}<5$ (moderate enrichment), $5 \leq \mathrm{EF}$ $<20$ (significant enrichment), $20 \leq \mathrm{EF}<40$ (very high enrichment), and $\mathrm{EF} \geq 40$ (extremely high enrichment) (22). A reference element is the one characterized by low-frequency current variability. The most common reference elements are $\mathrm{Sc}, \mathrm{Mn}, \mathrm{Ti}, \mathrm{Al}$, and $\mathrm{Fe}$ (23). The EF is calculated using the following expression:

$\mathrm{EF}=\left[(\mathrm{Me})_{\mathrm{s}} /(\mathrm{Fe})_{\mathrm{s}}\right] /\left[(\mathrm{Me})_{\mathrm{b}} /(\mathrm{Fe})_{\mathrm{b}}\right]$

where $(\mathrm{Me})_{\mathrm{s}}$ and $(\mathrm{Me})_{\mathrm{b}}$ are the concentrations of metal and normalizer, respectively. Also, $(\mathrm{Fe})_{\mathrm{s}}$ and $(\mathrm{Fe})_{\mathrm{b}}$ denote the sample and background sediments, respectively. Data were analyzed using SPSS version 16.

\section{Results}

Table 1 shows the concentrations of heavy metals in sediment samples collected from intertidal zone from four regions in the Bushehr province.

The obtained Igeo values for these four regions are shown 
Table 1. Mean concentrations of each metal analyzed $(\mathrm{mg} / \mathrm{kg})$

\begin{tabular}{lcccc}
\hline \multirow{2}{*}{ Metals } & \multicolumn{3}{c}{ Region } \\
\cline { 2 - 5 } & Ameri Port & Bushehr Port & Imam Hassan Port & Nayband Bay \\
\hline $\mathrm{As}$ & $16.24 \pm 8.76$ & $5.03 \pm 0.15$ & $3.31 \pm 2.65$ & $1.55 \pm 0.49$ \\
$\mathrm{Cr}$ & $16.82 \pm 3.05$ & $14.29 \pm 7.79$ & $10.96 \pm 3.30$ & $10.19 \pm 5.97$ \\
$\mathrm{Cu}$ & $5.5 \pm 0.88$ & $5.5 \pm 2.83$ & $3.75 \pm 0.49$ & $3.45 \pm 0.77$ \\
$\mathrm{~Pb}$ & $12.27 \pm 4.59$ & $2.77 \pm 0.38$ & $3.03 \pm 0.02$ & $6.35 \pm 4.30$ \\
$\mathrm{Zn}$ & $14.20 \pm 1.41$ & $11.45 \pm 8.13$ & $8.45 \pm 1.06$ & $4.75 \pm 0.78$ \\
$\mathrm{Al}$ & $3980 \pm 462.4$ & $4189 \pm 53143.09$ & $3828.5 \pm 688.01$ & $695 \pm 173.2$ \\
$\mathrm{Fe}$ & $8420 \pm 1824.3$ & $5360 \pm 3309.26$ & $4141 \pm 642.05$ & $773.5 \pm 193.04$ \\
$\mathrm{Ni}$ & $18.07 \pm 2$ & $13.4 \pm 6.36$ & $11.8 \pm 3.25$ & $8.19 \pm 2.25$ \\
$\mathrm{Sb}$ & $0.45 \pm 0.07$ & $0.35 \pm 0.21$ & $0.35 \pm 0.07$ & $0.55 \pm 0.07$ \\
$\mathrm{Cd}$ & $0.07 \pm 0.04$ & $0.18 \pm 0.01$ & $0.10 \pm 0.04$ & $B D L^{*}$ \\
\hline
\end{tabular}

*BDL: Below detection limit.

in Table 2.

Spearman correlation matrix was calculated between all the trace metals (and also major elements) and corresponding sampling regions (Table 3).

EF was used as an index to evaluate anthropogenic influences of heavy metals in sediments. When $0.5 \leq \mathrm{EF} \leq$ 1.5 , the trace metals might have originated entirely from crustal materials or natural weathering processes, while when $\mathrm{EF}>1.5$ suggested that a significant portion of trace metals is provided by other sources (24).

\section{Discussion}

In this study, sediment pollution was assessed using geoaccumulation index (Igeo) and EF. As can be seen in Table 1, metal levels in all areas of the sample sites in terms of frequency were $\mathrm{Fe}>\mathrm{Al}>\mathrm{Cr}>\mathrm{Ni}>\mathrm{Zn}>\mathrm{As}>\mathrm{Pb}>$ $\mathrm{Cu}>\mathrm{Sb}>\mathrm{Cd}$. The relatively high concentrations of heavy metals during winter coincide principally with decreasing rate of organic matter decomposition, due to a low water temperature (25). The highest concentrations of Fe and $\mathrm{Al}$ were found in Ameri port while the lowest values of $\mathrm{Cd}$ were reported in Nayband Bay. Fe, $\mathrm{Al}$, and $\mathrm{Pb}$ levels were found to be higher than the other metals in the four regions (Table 2). Approximately, $42 \%$ of the samples were included in Class 0 . A small percentage of the samples was included in Class 2, 3, and 4 for $\mathrm{Al}, \mathrm{Fe}, \mathrm{Cd}$, and $\mathrm{Pb}$. There were significant inter-elemental correlations (e.g., Cr-Fe, $\mathrm{Cr}-\mathrm{Al}, \mathrm{Cr}-\mathrm{Ni}, \mathrm{Cr}-\mathrm{Zn}$, and $\mathrm{Cr}-\mathrm{Cu}$ ). Inverse correlations

Table 2. Index of geoaccumulation for sampling regions

\begin{tabular}{|c|c|c|c|c|c|c|c|c|c|}
\hline \multirow{2}{*}{ Region } & \multicolumn{9}{|c|}{ Class } \\
\hline & $\mathrm{Fe}$ & Al & $\mathrm{Cd}$ & $\mathrm{Pb}$ & $\mathrm{Ni}$ & As & $\mathrm{Zn}$ & $\mathrm{Cu}$ & $\mathrm{Sb}$ \\
\hline Imam Hassan & 0 & 2 & 0 & 0 & 0 & 1 & 0 & 0 & 1 \\
\hline Bushehr & 3 & 3 & 2 & 2 & 0 & 1 & 0 & 0 & 1 \\
\hline Ameri & 4 & 3 & 0 & 3 & 0 & 1 & 0 & 0 & 1 \\
\hline Nayband & 3 & 2 & 0 & 2 & 0 & 0 & 0 & 0 & 1 \\
\hline
\end{tabular}

Table 3. The Spearman correlation matrix between element levels in the sediment of the Persian Gulf

\begin{tabular}{|c|c|c|c|c|c|c|c|c|c|c|}
\hline & $\mathrm{Cr}$ & Al & $\mathrm{Fe}$ & $\mathrm{Ni}$ & As & $\mathrm{Cu}$ & $\mathrm{Pb}$ & $\mathrm{Zn}$ & $\mathrm{Sb}$ & $\mathrm{Cd}$ \\
\hline $\mathrm{Cr}$ & 1 & & & & & & & & & \\
\hline $\mathrm{Al}$ & .934 & 1 & & & & & & & & \\
\hline $\mathrm{Fe}$ & $1.000 * *$ & .927 & 1 & & & & & & & \\
\hline $\mathrm{Ni}$ & $.997 * *$ & .901 & $.998 * *$ & 1 & & & & & & \\
\hline As & .857 & .639 & .865 & .891 & 1 & & & & & \\
\hline $\mathrm{Cu}$ & .947 & $.999 * *$ & .940 & .917 & .667 & 1 & & & & \\
\hline $\mathrm{Pb}$ & .131 & -.233 & .150 & .213 & .557 & -.195 & 1 & & & \\
\hline $\mathrm{Zn}$ & $.996 * *$ & $.961^{*}$ & $.995^{* *}$ & $.986 * *$ & .816 & .971 & .046 & 1 & & \\
\hline $\mathrm{Sb}$ & -.724 & -.923 & -.711 & -.664 & -.310 & -.907 & .589 & -.780 & 1 & \\
\hline $\mathrm{Cd}$ & .317 & .570 & .303 & .253 & .072 & .546 & -.715 & .381 & -.756 & 1 \\
\hline
\end{tabular}

*Correlation is significant at the 0.05 (2-tailed); ** Correlation is significant at the 0.01 (2-tailed). 
Table 4. Enrichment factor in sampling regions

\begin{tabular}{lcccccccccc}
\hline Metals Region & $\mathrm{As}$ & $\mathrm{Cr}$ & $\mathrm{Cu}$ & $\mathrm{Pb}$ & $\mathrm{Zn}$ & $\mathrm{Al}$ & $\mathrm{Fe}$ & $\mathrm{Ni}$ & $\mathrm{Sb}$ & $\mathrm{Cd}$ \\
\hline Imam Hassan & $\mathrm{EF}<2$ & $\mathrm{EF}<2$ & $\mathrm{EF}<2$ & $\mathrm{EF}<2$ & $\mathrm{EF}<2$ & $\mathrm{EF}<2$ & $\mathrm{EF}<2$ & $\mathrm{EF}<2$ & $\mathrm{EF}<2$ & $\mathrm{EF}<2$ \\
Bushehr port & $\mathrm{EF}<2$ & $\mathrm{EF}<2$ & $\mathrm{EF}<2$ & $\mathrm{EF}<2$ & $\mathrm{EF}<2$ & $2<\mathrm{EF}<5$ & $2<\mathrm{EF}<5$ & $\mathrm{EF}<2$ & $\mathrm{EF}<2$ & $\mathrm{EF}<2$ \\
Ameri port & $\mathrm{EF}<2$ & $\mathrm{EF}<2$ & $\mathrm{EF}<2$ & $2<\mathrm{EF}<5$ & $\mathrm{EF}<2$ & $2<\mathrm{EF}<5$ & $2<\mathrm{EF}<5$ & $\mathrm{EF}<2$ & $\mathrm{EF}<2$ & $\mathrm{EF}<2$ \\
Nayband Bay & $\mathrm{EF}<2$ & $\mathrm{EF}<2$ & $\mathrm{EF}<2$ & $\mathrm{EF}<2$ & $\mathrm{EF}<2$ & $\mathrm{EF}<2$ & $\mathrm{EF}<2$ & $\mathrm{EF}<2$ & $\mathrm{EF}<2$ & $\mathrm{EF}<2$ \\
\hline
\end{tabular}

were observed between $\mathrm{Sb}$ and $\mathrm{Cd}$ with almost all other elements, suggesting a positive strong significant correlation among $\mathrm{Cr}, \mathrm{Al}, \mathrm{Fe}, \mathrm{Ni}$, and $\mathrm{Cu}$, which were clustered in the first class. Sb had a negative correlation with other elements in the first class. High EF level for $\mathrm{Fe}, \mathrm{Al}$, and $\mathrm{Pb}$ demonstrated that the levels of metals in sediments of the Persian Gulf could have originated from anthropogenic sources (Table 4). According to these results, the presence of these metals in the same groups might reflect a similar behavior or suggest common biooriginated sources.

The highest mean concentrations of $\mathrm{Pb}(12.27 \mathrm{mg} / \mathrm{kg})$, $\mathrm{Ni}(18.07 \mathrm{mg} / \mathrm{kg})$ and As $(16.24 \mathrm{mg} / \mathrm{kg})$ were reported in the Ameri port. This concentration was similar to the results of Ganugapenta et al (26) and Zhuang \& Gao (27) but lower than that of El Tokhi et al (21). The pollution in the Ameri port was higher than other ports, due to the increase in the amount of agricultural wastewater, industrial wastewater, oil pollution and shipping in this port compared to the other ports.

\section{Conclusion}

Oil extraction and recent regional wars in the Persian Gulf have released millions of oil barrels, including detectable trace metals, to the sea. Seawater desalination plants in the Persian Gulf with a capacity of millions cubic meters freshwater per day are another sources of heavy metal pollution in the area. In addition to pollutants, the contamination pattern of sediments is affected by factors such as sedimentation patterns, physical and chemical properties of the sediments. For example, sediments with fine-grained and high surface area-to-volume ratio can act as good absorbents for many pollutants.

\section{Acknowledgements}

The authors wish to thank all who assisted in conducting this research.

\section{Ethical issues}

The authors have thoroughly observed ethical issues and no data from the study has been or will be published separately elsewhere.

\section{Competing interests}

The authors declared no competing interests.

\section{Authors' contributions}

All authors contributed in all aspects of this research like performing surveys and experiments, preparing the figures and tables, designing the experiments, analyzing the data graphical elaborations, writing the manuscript, and providing critical revision of the paper.

\section{References}

1. Pekey H, Karakas D, Ayberk S, Tolun L, Bakoglu M. Ecological risk assessment using trace elements from surface sediments of Izmit Bay (Northeastern Marmara Sea) Turkey. Mar Pollut Bull 2004; 48(9-10): 946-53. doi: 10.1016/j.marpolbul.2003.11.023.

2. Sinem Atgin R, El-Agha O, Zararsız A, Kocataş A, Parlak H, Tuncel G. Investigation of the sediment pollution in Izmir Bay: trace elements. Spectrochim Acta Part B At Spectrosc 2000; 55(7): 1151-64. doi: 10.1016/S0584-8547(00)00231-7.

3. Rubio B, Nombela MA, Vilas F. Geochemistry of major and trace elements in sediments of the Ria de Vigo (NW Spain) an assessment of metal pollution. Marine Pollution Bulletin 2000; 40(11): 968-80.

4. Reimann C, de Caritat P. Intrinsic flaws of element enrichment factors (EFs) in environmental geochemistry. Environ Sci Techno 2000; 134(24): 5084-91.

5. Yang H, Rose NL. Distribution of mercury in six lake sediment cores across the UK. Sci Total Environ 2003; 304(1-3): 391-404. doi: 10.1016/s0048-9697(02)00584-3.

6. Capillo G, Silvestro S, Sanfilippo M, Fiorino E, Giangrosso G, Ferrantelli V, et al. Assessment of electrolytes and metals profile of the Faro Lake (Capo Peloro Lagoon, Sicily, Italy) and its impact on Mytilus galloprovincialis. Chem Biodivers 2018; 15(5): e1800044. doi: 10.1002/cbdv.201800044.

7. Abdolahpur Monikh F, Maryamabadi A, Savari A, Ghanemi K. Heavy metals' concentration in sediment, shrimp and two fish species from the northwest Persian Gulf. Toxicol Ind Health 2015; 31(6): 554-65. doi: 10.1177/0748233713475498.

8. Forouhar Vajargah M, Mohamadi Yalsuyi A, Hedayati A, Faggio C. Histopathological lesions and toxicity in common carp (Cyprinus carpio L. 1758) induced by copper nanoparticles. Microsc Res Tech 2018; 81(7): 724-9. doi: $10.1002 /$ jemt.23028.

9. Olubunmi FE, Olorunsola OE. Evaluation of the status of heavy metal pollution of sediment of Agbabu bitumen deposit area, Nigeria. Eur J Sci Res 2010; 41(3): 373-82.

10. Torre A, Trischitta F, Faggio C. Effect of $\mathrm{CdCl} 2$ on regulatory volume decrease (RVD) in Mytilus galloprovincialis digestive cells. Toxicol In Vitro 2013; 27(4): 1260-6. doi: 
10.1016/j.tiv.2013.02.017.

11. Savorelli F, Manfra L, Croppo M, Tornambe A, Palazzi D, Canepa S, et al. Fitness Evaluation of Ruditapes philippinarum Exposed to Ni. Biol Trace Elem Res 2017; 177(2): 384-93. doi: 10.1007/s12011-016-0885-y.

12. Burgos-Aceves MA, Cohen A, Smith Y, Faggio C. MicroRNAs and their role on fish oxidative stress during xenobiotic environmental exposures. Ecotoxicol Environ Saf 2018; 148: 995-1000. doi: 10.1016/j.ecoenv.2017.12.001.

13. Fernandez JM, Hayes PJ, Smith MR. Comprehensive Analytical Chemistry. Elsevier; 1992. p. 345-47.

14. Khoshnood Z, Mokhlesi A, khshnood R. Bioaccumulation of some heavy metals and histopathological alterations in liver of Euryglossa orientalis and Psettodes erumei along North Coast of the Persian Gulf. Afr J Biotechnol 2010; 9(41): 6966-72. doi: 10.5897/AJB10.944.

15. Sabzalizadeh S, Dehghan Madise S. Assessment of heavy metals pollution in the sediments of Lifeh-Busaf (northwest of Persian Gulf) using Geo-accumulation Index. Iranian Scientific Fisheries Journal 2010; 19(3): 51-60. [In Persian].

16. Pourang N, Nikouyan A, Dennis JH. Trace element concentrations in fish, surficial sediments and water from northern part of the Persian Gulf. Environ Monit Assess 2005; 109(1-3): 293-316. doi: 10.1007/s10661-005-6287-9.

17. Tatina M, Oryan S, Gharibkhani M. Surveying the amount of heavy metals $(\mathrm{Ni}, \mathrm{Pb}, \mathrm{Cd} \& \mathrm{~V})$ accumulation derived from oil pollution on the muscle tissue of Pelates quadrilineatus from the Persian Gulf. Mar Biol 2009; 1(1): 28-39. [In Persian].

18. Dehghan Chenari A, Lak R. Effects of heavy metals from petroleum pollutions on carbonate surface sediments of the Persian Gulf. Int J Environ Res 2014; 8(2): 297-304. doi: 10.22059/ijer.2014.720.

19. Ismail A, Badri MA, Ramlan MN. The background levels of heavy metal concentration in sediments of the west coast of Peninsular Malaysia. Sci Total Environ 1993; 134 (Suppl 1): 315-23. doi: 10.1016/S0048-9697(05)80032-4.

20. Muller G. Index of geoaccumulation in sediments of the Rhine River. GeoJournal 1969; 2: 108-18.

21. El Tokhi M, Amin BM, Alaabed SA. Environmental assessment of heavy metals contamination of bottom sediments of Oman Gulf, United Arab Emirates. J Pollut Eff Cont 2017; 5(4): 203. doi: 10.4172/2375-4397.1000203.

22. Tanner PA, Leong LS, Pan SM. Contamination of heavy metals in marine sediment cores from Victoria Harbour, Hong Kong. Marine Pollution Bulletin 2000; 40(9): 769-79.

23. Zhuang W, Gao XL.Acid-volatile sulfide and simultaneously extracted metals in surface sediments of the southwestern coastal Laizhou Bay, Bohai Sea: concentrations, spatial distributions and the indication of heavy metal pollution status. Mar Pollut Bull 2013; 76(1-2): 128-38.

24. Taylor SR, McLennan SM. The geochemical evolution of the continental crust. Rev Geophys 1995; 33(2): 241-65. doi: 10.1029/95RG00262.

25. Bazzi AO. Heavy metals in seawater, sediments and marine organisms in the Gulf of Chabahar, Oman Sea. J Oceanogr Mar Sci 2014; 5(3): 20-9. doi: 10.5897/JOMS2014.0110.

26. Ganugapenta S, Nadimikeri J, Chinnapolla SRRB, Ballari L, Madiga R, Nirmala K, et al. Assessment of heavy metal pollution from the sediment of Tupilipalem Coast, southeast coast of India. International Journal of Sediment Research 2018; 33(3): 294-302. doi: 10.1016/j.ijsrc.2018.02.004.

27. Zhuang W, Gao X. Integrated assessment of heavy metal pollution in the surface sediments of the Laizhou Bay and the coastal waters of the Zhangzi Island, China: comparison among typical marine sediment quality indices. PLoS One 2014; 9(4): e94145. doi: 10.1371/journal.pone.0094145. 